\title{
The Humanist LaWyer David Hilchen In the Polish Livonian ANd Polish Courts 1600 - 1609: The Reflection of His Proceedings in LetTers
}

\section{Introduction}

On 12 of July 1603, the Secretary to the Polish King, Livonian lawyer and humanist David Hilchen (1561-1610) ${ }^{1}$ - who was also a close collaborator of Jan Zamoyski (1542-1605), the Polish Chancellor and Grand Hetman of the Polish-Lithuanian Commonwealth - wrote to the Polish lawyer, translator and editor of the historical and contemporary political

The research and writing of this article is supported by grant PUT1030 from the Estonian Research Council. The authors thank Prof. Marju Luts-Sootak (Tartu) for her comments to the first draft of the article.

* Dr. iur., Associate Professor of Legal History and Roman Law in School of Law at University of Tartu and Lawyer-Linguist at European Court of Justice, e-mail: hesi.siimetsgross@ut.ee, https:/ / orcid.org/0000-0002-6568-8200.

** PhD, Senior Researcher in the Under and Tuglas Literature Centre of the Estonian Academy of Sciences (Roosikrantsi 6 Tallinn Estonia) and the General Secretary of the International Association for Neo-Latin Studies, e-mail: kristi.viiding@gmail.com, https://orcid.org/ 0000-0003-2488-7163.

1 See for the latest biography and inventory of his Latin correspondence 1577-1603: K. Viiding, T. Hoffmann, H. Siimets-Gross, P. Sapala (Eds.), The Correspondence of David Hilchen, in: Early Modern Letters Online, Cultures of Knowledge, http:/ / emlo-portal.bodleian.ox.ac.uk/collections/?catalogue=david-hilchen (access: 30.06.2020). See for further biographical details: H. von Ramm-Helmsing, David Hilchen 1561-1610. Syndikus der Stadt Riga, Posen 1936, pp. 19-46, and C. L. Gottzmann, P. Hörner, Lexikon der deutschsprachigen Literatur des Baltikums und St. Petersburgs, Berlin 2007, vol. 2, pp. 578-582. 
and legal texts, Paweł Szczerbicz (1552-1609), Syndic of Lviv, Secretary to the Polish King Sigismund III: ${ }^{2}$

In Kraków I saw [the manuscript of] your "Promptuarium". It still stays in my mind. Not only did I tell my lord [Jan Zamoyski] about it, I also wrote a poem in phalaecean hendecasyllables using my modest poetical skills. If it makes you happy, you can add my poem to your book. My lord would be happy if you would dedicate your book to him - he would show his gratitude. He is waiting for your book. ${ }^{3}$

Indeed, two years later, on opening the printed collection of Statutes and Decrees of the Polish-Lithuanian Commonwealth, "Promptuarium Statutorum Omnium et Constitutionum Regni Poloniae" ${ }^{4}$, even two poems by Hilchen were published: one in phalaecean hendecasyllables and

2 Paweł Szczerbicz (Paulus Sczirbicius, ca 1552-1609) - lawyer, syndic in Lviv, Royal secretary, and translator under the patronage of Jan Zamoyski. Both Stephan Bathory as well as Sigismund III trusted him the writing of provincial decrees. He translated many books into Polish, e.g. Speculum Saxonum, hoc est ius provinciale Saxoniae, ex optimis exemplaribus Latinis Teutonisque cum industria et fide maxima, in linguam Polonicam translatum per Paulum Scerbicz, Leopoli 1581; Ius municipale Magdeburgense. Ex optimis itidem Exemplaribus latinis ac teutonicis, pari studio ac fide Polonice reditum per Paulum Sczerbicz, Leopoli 1581; Justi Lipsii Politicorum sive civilis doctrinae libri sex, e latino sermone in Polonicum convertit Paulus Sczerbicz, Cracoviae 1595 (second edition 1598, third edition 1608, together with Lipsius De calumnia). In the modern literature Szczerbicz is often treated as a representative of Kraków School of Law, cf. e.g. H. Lück, Urban Law: the Law of Saxony and Magdeburg, in: H. Pihlajamäki, M.D. Dubber, M. Godfrey (Eds.), The Oxford Handbook of European Legal History, Oxford 2018, pp. 474-509, here p. 487. The intimate relationship between Hilchen and Szczerbicz was well known, cf. e.g.: "He was a close friend to David Hilchen, Royal Secretary and notary of Wenden Voivodeship in Livonia" ("Familiarissime autem amavit Davidem Hilchenium, Secretarium Regium, Terraeque Vendensis in Livonia notarium."; Ianociana sive clarorum atque illustrium Poloniae auctorum, vol. 2 Varsaviae et Lipsiae 1779, p. 11).

3 "Promptuarium Dominationis Vestrae quod Cracoviae vidi, ecce ut mihi in mentem etiam haereat. Nec tantum de eo cum Illustrissimo meo egi, verum etiam tenui musa mea, hoc phaleucion pangere volui. Quod si Dominationi Vestrae placebit, operi isti per me praemittere licebit. Dedicationem promtuarii Illustrissimus gratam habet, et de munere cogitat. Opus ipsum expectat." (Epistolae Davidis Hilchen, sex libris digestae ab anno 1600 usque ad annum 1610 in unum volumen redactae, ubi 715 epistolae reperiuntur. Riga LVVA 4038-2-297 fols. 86v-87r (liber 2,61); Liber Epistolarum. Linköpings Stads- och Stiftsbiblioteket, Br 43 fol. 139 r. (liber 2,61)).

4 Promptuarium Statutorum Omnium et Constitutionum Regni Poloniae per Paulum Scerbic Secretarium Sacrae Regiae Maiestatis conscriptum cum indice rerum et verborum copiosissimo singulari eiusdem Pauli Sczerbic studio et diligentia confecto, Brunsbergae 1605. 
the second, a short epigram, in elegiac distichs. In addition to praising Szczerbicz on his achievement using laudatory elements typical for Early Modern commendatory or liminary poems like these, ${ }^{5}$ Hilchen first outlines the ideal standard for laws, statutes and acts, including their linguistic form, as follows:

(1-4) When the laws, rights and statutes are clear and short and follow the consistent method, all will like them. (5-11) If you, kind reader, consider that as an achievement of someone else, it is not true: it is our achievement. And the author didn't just write that - he decides to dress the statutes with the decorated and pretty Latinity so that they would be easier to study. ${ }^{6}$

The first three elements - perspicuity, brevity and consistent methodical approach - were recognised as characteristics of an ideal legislation already during Roman times ${ }^{7}$ and again during humanism and successive eras. Those three elements are present both individually as well as in

5 Compare an updated overwiev of this early modern practice with terminological variety and references to the earlier research literature: H.-J. van Dam, Poems on the Threshold: Neo-Latin carmina liminaria, in: A. Steiner-Weber, K.A.E. Enenkel (Eds.), Acta Conventus Neo-Latini Monasteriensis. Proceedings of the Fifteenth International Congress for Neo-Latin Studies (Münster 2012), Leiden-Boston 2015, pp. 50-81. For Hilchen's poetry cf. David Hilchen, Sub velis poeticis. Lateinische Gedichte. Mit Übersetzungen und einer Einleitung herausgegeben von Kristi Viiding und Martin Klöker, Münster 2021.

6 "Leges Iuraque Constitutiones, / Si sint perspicuae, breuesque factae, / Traditae methodoque congruente, / Hoc cognouimus omnibus placere. / Hoc si quenquam alium benigne Lector,/ Praestitisse putas, putato nostrum / Praestitisse: nec illa praestitisse / Tantum: quin quoque Constitutiones / Aptatae studijs vt essent, / Ornataque venustiore veste / Latina, facit autor ille noster."

7 The same programmatic principles and keywords were mentioned in the introductory constitution of Justinian to his collection of laws "Deo auctore" (15.12.530) § 1: "Primum nobis fuit studium a sacratissimis retro principibus initium sumere et eorum constitutiones emendare et uiae dilucidae tradere, quatenus in unum codicem congregatae et omni superuacua similitudine et iniquissima discordia absolutae uniuersis hominibus promptum suae sinceritatis praebeant praesidium." ("It has been our primary endeavor to make a beginning with the most revered emperors of earlier times, to free their constitutiones (enactments) from faults and set them out in a clear fashion, so that they might be collected together in one Codex, and that they might afford to all mankind the ready protection of their own integrity, purged of all unnecessary repetition and most harmful disagreement" (A. Watson (Ed.), The Digest of Justinian, vol. 1, Philadelphia 2009). The Latin text stems from P. Krüger, T. Mommsen (Eds.), Corpus iuris civilis. Editio streotypa, vol. 1: Institutiones. Digesta, Berolini 1922. 
conjunction with each other in the works of different Classical and Early Modern authors. ${ }^{8}$ What is, however, contrary to the trends of Hilchen's era, is the fourth element - Latin as the ideal language for local laws. ${ }^{9}$ Hilchen underlines the importance of translations of Polish laws and statutes into Latin, stressing the controversial legal situation in the Polish-Lithuanian Commonwealth at the end of the poem. From the intrinsic Polish-Lithuanian aspect, use of vernacular languages was acceptable. From the extrinsic international view, the lawyers from other regions thought that Poles and Lithuanians are "still wandering without laws". ${ }^{10}$ Thus, the book by Szczerbicz is in Hilchen's opinion not only a clear, compact and methodologically perfect collection of laws and statutes, but also helps, with its partiality to the Latin language, to develop the international reputation of the Polish Law.

Who was the author of these programmatic poems? What was his merit in being the only one to publish two confident liminary poems for shaping the readers expectations and putting them into the right mood to enter the text, but also to rate and recommend an eminent book of the Polish Law as an expert guide? Ordering and writing such poems had been a common practice of communication since the invention of the printing press, ${ }^{11}$ and in many cases the commissioning of such a poem took place on the condition that the poet read the manuscript of the book carefully first. ${ }^{12}$ So at first glance it would have even been surprising that solely liminary poems by Hilchen - a nobleman of far-away Livonia - have been published in the collection. Which of Hilchen's experiences with the Polish legal system deserve further attention and wider contextualization to enrich our understanding about it?

8 About the central trends in the history of legislation in the 16th-18th century compare e.g.: H. Mohnhaupt, Grundlinien in der Geschichte der Gesetzgebung auf dem europäischen Kontinent vom 16. bis 18. Jahrhundert. Ein experimenteller Überblick, Zeitschrift für Neuere Rechtsgeschichte 2006, No 1/2, pp. 124-174.

9 A. Görgen, Rechtssprache in der Frühen Neuzeit. Eine vergleichende Untersuchungder Fremdwortwendung in Gesetzen des 16. und 17. Jahrhunderts, Frankfurt/M et al. 2002, esp. pp. 80-85.

10 V. 21-27 “Tibi ... Debebunt magis vsque dictitantes, / Polonos Litauosque iuris omnis / Expertes sine iure et vsque et vsque /Vagari." ("You will be thanked by all who repeat, that Poles and Lithuanians are still wandering without laws").

11 Van Dam, Poems on the Threshold..., pp. 56-60.

12 Ibidem, p. 64. 
The purpose of this paper is to introduce an almost unexplored Early Modern source, the unpublished Latin correspondence (ca. 760 letters) ${ }^{13}$ of the central humanist of Livonia ${ }^{14}$ and key figure in terms of legal, linguistic, literary and educational influence, David Hilchen, to the research of the Early Modern Polish history of law. As Hilchen's correspondence is voluminous and diverse, ${ }_{1}^{15}$ we can only map the principal issues touched by him in the context of his own legal proceedings before the Livonian and Polish courts against vice-syndic Godemann and Riga City Council. ${ }^{16}$ We will focus on the following questions:

1) If and how such a subjective genre as the private letter ${ }^{17}$ reflects the way a case arose and developed, moving between the courts of different levels and different territories in the Polish-Lithuanian Commonwealth?

13 The two main manuscripts of it are: Epistolae Davidis Hilchen, sex libris digestae ab anno 1600 usque ad annum 1610 in unum volumen redactae, ubi 715 epistolae reperiuntur. MS in Latvian State Historical Archives 4038-2-297, and Liber Epistolarum. MS in Linköpings Stadsoch Stiftsbiblioteket, $\mathrm{Br} 43$. Four books of letters in Linköping manuscript are identical with the books I-IV in Riga. A smaller number of the letters, esp. the letters to and from humanists in Germany and Low Countries, are in the care of the Herzog August Library in Wolfenbüttel; the State and University Library Hamburg Carl von Ossietzky; the Library of the Gymnasium Christianeum in Hamburg; and Basel University Library. Letters to Polish and Lithuanian correspondents are now in Central Archives of Historical Records in Warsaw.

14 1569-1621/29 Livonia was part of Polish-Lithuanian Commonwealth.

15 His correspondence involves letters written by him, to him, and letters he wrote as secretary on behalf of the other people.

16 Hereby, we will leave aside Hilchen's Latin and German political orations, which are unpublished as well. Likewise, we do not analyze laws, statutes and orders, compiled by him. The only additional source we will use, is the apologetical treatise by Hilchen Clypevs innocentiae et veritatis Davidis Hilchen. Serenissimi Sigismondi iii. Poloniae et Sveciae Regis Secretarij, et Notarij Terrestris Vendensis contra Iacobi Godemanni Loneborgensium et Rigensium quorundam, Senatus nomine ad proprium odium abutentium, cum iniquissima crudelissimaque quaedam decreta, tum alia calumniarum tela, editus, Zamosci 1604, and its German translation (Gegenwehr der Unschuld und Warheit. Wieder Jacob Godemans Luneburgensis, und etzlicher des Rathes zu Riga Rethleinfürer gesprengte calumnien, schme- und schandlibellen. Durch den Edlen und Ehrnvesten David Hilchen, Kon. May. zu Polen und Schweden Secretarien unnd Wendischen Landschreiber offentlich auffgestellet, Kraków 1605).

17 For the differences of the private and official letters in the Early Modern period cf. e.g. J. Rice Henderson, Humanist Letter Writing: Private Conversation or Public Forum?, in: T. Van Houdt, J. Papy, G. Tournoy, C. Matheuussen (Eds.), Self-presentation and Social Identification. The Rhetoric and Pragmatics of Letter Writing in Early Modern Times, Leuven 2002, pp. 17-38. 
Which subgenres of letters were used ${ }^{18}$ Were, e.g., the letters in genus iudiciale preferred?

2) Could the private letter have a significance as a medium to the outcome of the proceedings?

3) Starting as a private dispute about iniuria between private persons and ending as a case of treason, was the case handled as ordinary or as a political legal proceeding?

\section{First Contacts with the Polish Legal System 1585-1599: The Perspective of the Representative of the City Riga and Livonia}

During Hilchen's lifetime Livonia or Livland, divided today between the Baltic States Estonia and Latvia, belonged to the Polish-Lithuanian Commonwealth (1569-1621/29). Despite Hilchen's origin from a German merchant family of Riga and the education of his older brother Johannes in medicine, David decided to study law, at that time mainly Roman law. There were no universities in Livonia and Estonia before 1632. Hilchen, however, chose for his study neither Poland nor Lithuania, ${ }^{19}$ but the German universities of Ingolstadt (as the tutor of the Lithuanian nobleman Alexander

18 In the Renaissance classification of the letters the three types were distinguished following the example of classical rhetorics: letters in genus deliberativum, genus demonstrativum, and genus iudiciale. Erasmus added a fourth type to these: genus familiare (Erasmus Rotterodamus, De conscribendis epistolis opus, Lugduni 1542). To the deliberative letters belonged e.g. the letters of recommendation and dissuasion, of consolation, petition, conciliation, communication, disputation, hortatory, monishing letters etc. To the genus demonstrativum belonged the letters of approval and disapproval. To the judicial letters (genus iudiciale) belonged the accusatory, complaining, minatory, defensive, justifying, apology, invective letters etc; to the familiar letters the narration, information, mandatory, joking, congratulatory, lamentative letters, greetings and thank you letters, dedications etc. Especially the longer letters belonged, however, to the type of epistolae mixtae (mixed letters), in which different parts had different function. For the overview about Early Modern letter-writing manuals with different typologies of letters compare: P. Mack, A History of Renaissance Rhetoric 1380-1620, Oxford 2011, pp. 228-256.

19 About the possibilities of Catholic and Protestant education in the territory of Polish-Lithuanian Commonwealth compare: chapter 1.1. Universities in the Polish-Lithuanian Commonwealth, in: V. Lepri, Knowledge Transfer and the Early Modern University: Statecraft and Philosophy at the Akademia Zamojska (1595-1627), Leiden 2019, pp. 1-7. 
Słucki), Tübingen (as the tutor of the Polish noblemen, brothers Jakob and Barthold Zielenski de Zelancha) and Heidelberg (1580-1585).$^{20}$ In the two disputations, written and defended by Hilchen in Tübingen and Heidelberg about legal topics, there could not be found any special interests in Polish legislation despite the fact that the disputations were dedicated to the Polish high official Jan Zamoyski and Polish nobleman Hieronymus Zaklika. ${ }^{21}$

Returning from his studies in 1585, David Hilchen was asked to help settle the Calendar Riots in Riga, the conflict between the Riga City government and the citizens who refused to accept the transition to the Gregorian calendar and to hand over Jacob's Church to the Jesuits. The introduction of the new calendar, decreed by the pope, was seen as a violation of religious liberties of Protestants..$^{22}$ Hilchen's ability to reconcile the parties and help to finish the riots with the "Severini-Day Contract" was appreciated highly - at least at first - by both parties. Hilchen was first nominated by the City of Riga as the Secretary of Riga (the post was vacated during the Riots) and then, on 2nd November 1589 as the Syndic of Riga. He continued in the latter position for more than ten years. The Polish side ennobled Hilchen in 1591 according to the proposal made by Severin Bonar and Lew Sapieha, the same persons who represented Polish government during the settling of the Riots. ${ }^{23}$

${ }^{20}$ Ingolstadt, Tübingen and Heidelberg were not common German universities for the Livonian Baltic German students in this time. Instead of them, Rostock, Wittenberg, Königsberg, Leipzig, Frankfurt/Oder, Jena and Helmstedt were attended (A. Tering, Eesti-, liivi- ja kuramaalased Euroopa ülikoolides 1561-1798 [Estonians, Livonians and Curonians in the European Universities 1561-1798] Tartu 2008, pp. 297-299).

21 D. Hilchen, Disputatio de successione ex testamento. Qvam Divini numinis auspicio, praeside clarissimo viro D. Andrea Laubmario, V.I.D. et in celeberrima Tubingensi Academia ordinario professore, praeceptore suo singulariter observando, die 29. Maji hora 6. In auditorio Jureconsultorum, ingenij exercendi gratia, defendere conabitur David Heliconius, Livonus, Tubingae 1584; D. Hilchen, De legatis et fideicommissis disputatio in antiqua Heidelbergensi academia sub excellentissimi viri Domini Matthiae Entzellini V.J.D. et professoris ordinarii: Praeceptoris sui omni officio observandi praesidio: ingenii retexendi gratia publice proposita a Davide Heliconio Livono die 20. Februarii horis ante et pomeridiani discutienda, Heydelbergae 1585.

${ }^{22}$ For more see: A. Ziemlewska, "Rozruchy kalendarzowe" $w$ Rydze (1584-1589), Zapiski Historyczne 2006, No 1, pp. 107-124.

23 B. Trelińska, Album armorum nobilium Regni Poloniae XV-XVIII saec: herby nobilitacji i indygenatów XV-XVIII w., Warszawa 2001, p. 232, No. 529. 
As a lawyer, Hilchen compiled numerous laws and regulations for Riga, including the Act of Church Council (Konsistorialordnung, 1588), the Act on Orphans' Court (Waisengerichtsordnung, 1596), the Regulation of Chancery (Kanzleiordnung, 1598), as well as for Livonia, e.g. the Territorial Law (Landrecht, 1599). ${ }^{24}$ Influenced by his studies in the Humanist Era in Germany, Hilchen tried to live up to the Renaissance ideal: active in the educational field as a scholarch, he reformed the Cathedral School into a humanist gymnasium and wrote the new school rules (Ratio docendi) in $1594 .{ }^{25}$ To add, he was the representative of the City of Riga and the nobility of Livonia in the Polish Sejm or the Parliament, whilst being the Secretary to the Polish king Sigismund III Vasa (Secretarius Regiae Maiestatis) and a notary of Wenden (Notarius Terrestris Vendensis). ${ }^{26}$

From these politically and diplomatically active years only very few (36) letters by and to Hilchen are preserved: 14 by Hilchen (the earliest from 1588 to an anonymous fellow citizen of Riga), 22 to Hilchen (the earliest from 1577 by the professor Johannes Caselius from Rostock). There is only one letter from this period, which illustrates Hilchen's engagement with the Polish legal system. It is a short communicative letter written by the aforementioned lawyer Paweł Szczerbicz, to ask about Hilchen's position regarding the trial of Guntherus. As the letter is short, it is not quite clear what was Hilchen's role in that trial which started with hearings in

24 Two of them are edited and commented in the modern times. For the Territorial Law s. T. Hoffmann. Der Landrechtsentwurf David Hilchens von 1599: Ein livländisches Rechtszeugnis polnischer Herrschaft. Frankfurt 2007; for the Regulation of Chancery see M. Mahling. Die Kanzleiordnung des Rigaer Rats von 1598. Historischer Kommentar und Edition, Archiv für Diplomatik, Schriftgeschichte, Siegel- und Wappenkunde 57 (2011), pp. 181-204.

25 Orationes tres: E quibus duae honoratissima dignitate, tum sapientia et virtute ornatissimorum D.D. Scholarcharum, Nicolai Ekii, Proconsulis: et Davidis Hilchen Syndici. Tertia Ioannis Rivii, cum solenni et publico ritu produceretur, ad demandatam sibi ab Amplissimo Senatu Inspectionem Scholasticam Ineundam. Habitae in restitutione seu instauratione Scholae Rigensis XV. CLS. VILS. Adiuncta sunt iisdem: primum, publicae doctrinae series, tabellis expressa: inque curias $V$. distributa. Deinde, docendi in singulis curiis, praescripta ratio et demonstratum iter, quod utiliter Praeceptores hujus Ludi sequerentur: cum in tradendis artibus: tum in tractando et interpretando omni genere, utriusque linguae, Autorum, Rigae 1594.

${ }^{26}$ For details see: H. von Ramm-Helmsing, David Hilchen..., pp. 19-46. 1582-1598 Wenden was Presidency, since 1598 Voivodeship, centre of local government of the Duchy of Livonia and of the catholic diocese. The capital of it was the town Wenden (Polish: Kies), where local sejmiks of the nobility took place. 
Brest. It is apparent that without hearing Hilchen's position, the process could not move further. ${ }^{27}$

\section{1600-1601: Hilchen's Legal Proceedings in the Courts of Polish Livonia}

Already by the 1590s, not all fellow citizens of Riga applauded Hilchen's activities and his way of achieving them. About some of the attacks on him Hilchen wrote in his letters, ${ }^{28}$ to the other attacks he or his fellow humanists, e.g. Daniel Hermann, reacted in poetical form, compiling and publishing Latin satires, warning poems and epigrams. ${ }^{29}$ It seems that the last two drops in the 'cup of bitterness' fell in the concluding

27 Nobili et Egregio Domino, Regio Secretario / Rigensis Civitatis amico suo charissimo. / 25. Aprilis anno 89 Warsaviae / Dominus Scerbicz. / Egregie Domine Secretari./ Guntherus hesterna die efflagitavit vt causa eius hodie proponeretur de quo Dominationem Tuam certiorem feci. Nunc velim scire vtrum procedendum animus sit Dominationis Vestrae necne? Hoc enim in vtramque partem facile efficitur. Si enim Dominationes Vestrae volent experiri iure, possunt, siquidem adversarius instat. Si nolint facile et iste reijcietur, nam causa haec in Limitationis Gunteri incidit, ita vt invitis Dominis Vestris audiri non possit, quod enim Brestis audita est. Hoc propterea factum est, quod tum ex Limitationis Gunteri causis Livonicis erant exceptae, quod in praesenti Limitatione factum non est, futurum tamen Lublini in prorogatione istius Gunteri Limitationis. Bene valeat et me amet. please add space between dot and Est.Est quod adhuc alloquar: Dominationem Vestram rogo antequam discedat, faciat mihi sui copiam.

Amicus obsequens

P. Sczerbiz

Manu Propria

(ms. autograph: Riga LVVA 673-3 (K-12)-51, fol. 1r-1v).

28 E.g. in the communicative letter to Jan Zamoyski 1599-10-26 (ms. apograph in Warszawa Archiwum Glowne Akt Dawnych, 358 Archiv Ord. Zamoiskich Tom VII, Plik 66 fols. 14-15): "I suspect that some kind of Aristarchus is about to be sent to the King's court to whisper to His Majesty lies, especially about me, because he does not dare touch other commissars because of their dignity" ("Suspicor enim in aulam Aristarchum quondam missum iri, qui falsa Sacrae Regiae Maiestati insusurrat, contra me praesertim, quia caeteros Commissarios ob dignitatis amplitudinem tangere non audent.").

29 Catharini Santonellae Horti Musarum in Monte Helicone custodis [=David Hilchen] contra Cerberum [=Georg Herbers] in Elysijs vallibus excubitorem Heliconi oblatrantem Satyra, S.l, s.a. [Riga 1599]. Edited with prosopographical, mythological and historical commentary: K. Viiding, Gefährliche Bücher, gefährliche Gattungen, gefährliche Vorlagen: Die Geburt der Satire 
months of $1599,{ }^{30}$ when Hilchen made public a corruption case of the burgrave and mayor of Riga, Nicolaus Eck(e), and came into conflict with his own vice-syndic in Riga, Jakob Godemann. ${ }^{31}$ Hilchen beat Godemann in public, in the foreyard of Riga castle, with rods for his second had not obeyed him. ${ }^{32}$ The latter incident was the official motive to start court proceedings that lasted from January 1600 to June 1609, for nine years, and gave Hilchen plenty of reasons to publish an apologetic treatise in Latin and German ${ }^{33}$ as well as to send many Latin letters to Polish and Lithuanian high officials, to foreign lawyers and humanists. Also, his case caused an intensive correspondence between different high officials of the Polish-Lithuanian Commonwealth and the City of Riga.

There were actually two different proceedings: one about iniuria against Godemann, another about high treason proceedings. ${ }^{34}$ Secondary literature, e.g. von Ramm-Helmsing, has so far emerged from just one court case as the two proceedings were partly treated in court together. ${ }^{35}$ Additionally, as Hilchen himself claimed, there was also some misunderstanding about procedural roles: who is plaintiff, who is defendant, etc. ${ }^{36}$

On 24th (14th) January 1600, Hilchen was first called to the hearing to the City Hall in Riga, and then arrested with the assurance of receiving the proper accusation after 24 hours. As the accusation could not be

in Livland, in: O. Merisalo (Ed.), Book in context, Renæssanceforum 2019, No 15, pp. 73-99 (http://www.renaessanceforum.dk/rf_15_2019.htm).

30 The exact dates are not verified. See about one possibility S. Leliwa, Dawid Hilchen. Szkic biograficzny na tle dziejów inflancko-polskich osnuty, "Biblioteka Warszawska“ 1880, 157.1, pp. 2-27, 383-390.

31 See for the position of Godemann described in: S. Leliwa, Dawid Hilchen..., pp. 2-27, 383-390.

32 D. Hilchen, Gegenwehr..., fol. A3 v.

33 D. Hilchen, Clypevs...; D. Hilchen, Gegenwehr...

34 Compare information about two trials in Hilchen's defensive and petitive letter to Friedrich Bartsch SJ 5th September 1602; about his process against the City of Riga in Hilchen's petitive letter to Andrzey Nowak SJ on 23th January 1603 ("causa mea, quae cum Senatu Rigensi mihi intercedit").

35 H. von Ramm-Helmsing, David Hilchen..., pp. 55-59.

36 Hilchen's narrative and petitive letter to Zamoyski. 1600-12-10. ms. apograph in Warszawa Archiwum Główne Akt Dawnych, 358 Archiv Ord. Zamoiskich Tom VII, Plik 66, fols. 20-23. See also H. Siimets-Gross, A Letter from Detention: The Edition of Letters of Livonian Humanistic Lawyer David Hilchen as an Interdisciplinary Challenge, in: V. Amorosi; V. M. Minale (Eds.), History of Law and other Humanities: Views of the Legal World Across the Time, Madrid 2019, pp. 391-405. 
presented so quickly, Hilchen was released following the intervention of some local noblemen as well as of the Voivode of Wenden and Commander-in-Chief of the Polish Army in the Polish-Swedish War Jürgen von Fahrensbach (Polish Jerzy Farensbach, 1551-1602) on the $25^{\text {th }}\left(15^{\text {th }}\right)$ of January. Hilchen promised to present himself to the court six weeks later. In March, high officials of the Polish-Lithuanian Commonwealth, Jan Zamoyski and Petrus Tylicki ${ }^{37}$ wrote defensive letters to support Hilchen, asking for a fair and unpolitical trial. ${ }^{38}$ From the other side, Lew Sapieha, the Chancellor of Lithuania and an old friend of Hilchen, wrote in this initial stage of the trial in May 1600 to the burgrave and City Council of Riga a conciliative letter, recommending to "finish the trial with a friendly settlement, not with the strictness of the law." ${ }^{39}$

Crucial for the further development of Hilchen's trials was the "Inhibitio Sacrae Regiae Maiestatis" from the $19^{\text {th }}$ of March 1600 by which King Sigismund III gives the order to hand over the proceedings that "the City of Riga has initiated against the aforementioned, our Secretary, to Us and Our Court". ${ }^{40}$

Hilchen described the first few months of his proceedings in many letters, e.g. to Jan Dymitr Solikowski (1539-1603), the Archbishop of Lviv, that his case "was heard and his innocence proven, but since one person had opposed, no sentence was made and the case was taken up by His Majesty. But the case is not moving forward in the Relationsgericht ${ }^{41}$ like

37 Piotr Tylicki (1543-1616) was during the decade of Hilchen's troubles one of the most influential persons in Poland: Vice-Chancellor (1598-1605), Bishop of Warmia (1600-1604), Bishop of Kujawy (1604-1606), since 1607 bishop of Kraków.

38 D. Hilchen, Gegenwehr..., Appendix, fols. J4r-K3v and K3v-K4r. The Latin autograph by Zamoyski (as well as its translation) is preserved in Riga LVVA 673-1-344d pp. 253-260.

39 "In eadem causa cum Davide Hilchen ut Dominationes Vestrae amicabili compositione rem ad finem perducant quam rigore iuris exequantur lubenter velim: qua in re non dubito Dominationes Vestras quod aequitas rei et commodum civitatis postulaverit facturas" (Riga Pilsetas Archivas LVVA-673-1-344b pp.460-461).

40 D. Hilchen, Gegenwehr..., Appendix, fol. Ar-Av.

${ }^{41}$ Relationsgericht was one of the appellation instances in the Polish-Lithuanian Commonwealth together with comitia particularia (court of the parlament in special matters), conventus generalis (parlament) etc. In the Relationsgericht was Polish King the chairman of the court and it gathered usually in March and in October. It had competence over cases that were not in the competence of the chancellors or assessorial courts. A. C. A. Friedric, Darstellung Alt- und Neupolens, Berlin 1839, p. 290; S. Hüppe, Verfassung der Republik Polen, Berlin 1867, p. 288. 
the fringe [on the] clothing of God." 42 Although Hilchen was accused of high treason in the Riga City Hall already in January 1600, it is probable that the official accusation with summons to the court was presented only in the end of May. A younger friend from Riga, future (1603) doctor iuris in Leiden, ${ }^{43}$ Caspar Dreiling Junior (1572-1631) wrote to him on 5th June 1600 in a long narrative letter:

When I arrived in Riga on the 13th day of my journey, I found your case in a strange state, and I realized that, despite the king's ban, a public summons [to Hilchen] had been struck in criminal cases - and in different places - and many different rumours had been spread. I had a conversation with the highborn Castellan of Wenden, who seriously reminded the City Council [of Riga] of the royal ban to which the Riga City Council did not respond. When [Castellan of Wenden] asked about the same matter, the mayor did not answer but said that Hilchen and his helpers were indeed under suspicion, though that the inner voice of conscience should rather be heard in this matter. [...] In fact, the people laugh at all court assessors. The syndicus [Hilchen] is successful in the court cases of others but incapable in his own." ${ }^{44}$

42 "Audita quidem est causa, et congruentibus votis innocentia mea approbata. Sed unus instar omnium obstitit, quo minus sententia lata, sed causa ad Regiam Maiestatem recepta fuerit. Haeremus itaque in relatione velut fimbria Dei." 1600-05-10, ms. apograph: Riga LVVA 4038-2-297 fol. 1r-1v (liber 1,1); Linköpings Stadsbibliotek/Stiftsbiblioteket, Br 43, fols. 3r-4r. (liber 1,2). For the comparison velut fimbria Dei cf. Augustinus Sermones 63/A.3 Sermo de muliere quae fluxum sanguinis patiebatur: "Ergo Paulus apostolus missus ad gentes, ipse est fimbria vestimenti Domini, quia ipse erat novissimus Apostolorum." Similarly Hilchen wrote on 15th of May 1600 to the Secretary to Polish King, lawyer, and chronicler Reinhold Heidenstein (1553?-1620). From Heidenstein he asked also for the first time (known to us) an expert opinion about the dispute in court in a form of a judicium. ms. apograph: Riga LVVA 4038-2-297, fol. 219v (liber 5,144).

43 A. Tering, Lexikon der Studenten aus Estland, Livland und Kurland an europäischen Universitäten 1561 -1800. Unter Mitarbeit von Jürgen Beyer (Quellen und Studien zur baltischen Geschichte 28), Köln, Weimar, Wien 2018, p. 270, no 1494.

44 “Decima tertia, itineris susceptae die, Rigam veni, mirabilem causae Generosae Dominationis Vestrae statum inveniens, Citatio Criminalis publice Contra Regiae Maiestatis Inhibitionem affixa fuit, de qua varij variae loquuntur, iudicio tamen vulgi. Alloquium mihi fuit apud Illustrem Dominum Palatinum Vendensem, qui se negotio interposuit, Senatum Regiae inhibitionis seuere admonens, sed responsum indies expectans. Contuli ea de re ipse cum spectabili Proconsule, qui nihil responsi dederat, sed suspectum se Generosae Dominationi Vestrae et ipsis quoque complicibus dixerat, sed probum interno iudice conscientiae scilicet se audire. [...] Immo in Dominorum Assessorum omnium irrisum vulgus dixit. Dominus Syndicus tanta cum laude aliorum negocia gessit, et proprijs male 
Dreiling also details other rumours in Riga, about the robbery and destruction of a Hilchen's estate during the time Hilchen was not at home, etc.

At that time Hilchen himself was in Warsaw and wrote to Jan Zamoyski "in his highest necessity." According to the letter to Zamoyski on 6th June 1600, Hilchen had sent him on 30th May several documents necessary for his trial and wished that Zamoyski would approach the Polish Vice-Chancellor on his behalf. As Hilchen had not received Zamoyski's answer so far, he is writing again for Zamoyski's advice and help. ${ }^{45}$

Only couple of days later, on 10th June 1600 the king has signed a first sentence in the trials between Hilchen and the City of Riga and also between Hilchen and Godemann. ${ }^{46}$ In this sentence the king clearly distinguishes between two processes. The legal proceedings between Hilchen and the City of Riga should be postponed and moved "till the moment when our counsellors will come more often together" ${ }^{47}$ The proceedings with the Godemann "as the proceedings" between private persons have to be referred to the ordinary court. ${ }^{48}$ The king mentions also his decree about the right to move freely to the session and from the session without any violence and stresses that both, the appeal in the "proceedings about the honour and good reputation" but also appeals in other questions, which will be allowed with any restriction.

consulit. Suspectus alijs sermo fuit alijs verus." (1600-06-05. Caspar Dreiling Junior to David Hilchen. ms. autograph: Riga LVVA 673-1-344e pp. 463-466).

45 1600-06-07. ms. apograph: Warszawa Archiwum Głowne Akt Dawnych, 358 Archiv Ord. Zamoiskich Tom VII, Plik 66, fols. 18-19. From the structure, it is a mixed letter: after recalling his previous wish, Hilchen mediates Livonian news.

46 Das erste Urtheil der Königlichen Majestät, in: D. Hilchen, Clypeus..., fols. Aii-Aiv verso; D. Hilchen, Gegenwehr..., fols. G2v-Hr. The sentence was published in Vilnius by Salomon Sulzer in Latin as well as in German: Decretum regium inter generosum Davidem Hilchen Sacr. Reg. Mtis. et Secretarium et Notarium Terrestrem Vendensem Actorem: et Spectabilem Senatum Rigensem, una cum parte adhaerente egregio Iacobo Godemano Citatum Varsaviae die X. Iunij Anno MDC latum. Cui adnexum est Rescriptum Regium, Vilnae MDC (the only copy in Geheimes Staatsarchiv Preussischer Kulturbesitz Berlin sign. XX EM 90/124, nr. 60, fols. 36-41) and Königlicher Mayestat DECRET vnnd MANDAT, die zwischen dem Edlen vnnd Ehrnuesten Dauid Hilchen Königlichen Secretarien inn Liffland ond Wendischen Landt Notarien Klegern/ vnnd einem Erbaren Ratth von Riga Beklagte zunebenst dem Namhafften Jacob Godeman jungsthin zu Warschaw den 10 Junij 1600 ergangen, Gedruckt inn der Königlichen Statt Wilde [sic] Anno 1600 (the only copy in Copenhagen Royal Library, sign. 188, 280. 00573).

47 D. Hilchen, Clypeus..., fol. Aiv; D. Hilchen, Gegenwehr..., fol. G4v.

48 It means, to Riga Castle Court. D. Hilchen, Clypeus..., fol. Aiiir. 
According to the king, this does not affect the privileges of the City of Riga given by Stephen Bathory. ${ }^{49}$

Zamoyski is clearly the person to whom Hilchen wrote often and who also heard about the details of the trial. The description by Hilchen from 10th December 1600 about how the order of the king was respected is not favourable for holding the court in Riga. In order to conduct the trial in accordance with the royal decree, Hilchen asked the council to hand over the relevant documents and to assure him that nothing would happen to him - but he was unable to achieve either. The one promise made to him by the king, namely the right of free passage, was finally not granted to him by the Riga City Council. The summons against Hilchen had not been properly announced by an edict on the door of the City Hall. Hilchen, for his part, had sent both a lawyer from Prussia named Johannes Myrander ${ }^{50}$ and a procurator (mentioned without name). Both were excluded under legal pretexts as in criminal cases. Even though they would have been refuted under common law, Saxon and Polish law, they were not even heard. Hilchen, however, was absent for he had to fulfil duties towards Polish Kingdom as, in the war of the Polish King against Duke Charles in Livonia, he was defending the Lemsal (Limbaži) Fortress, entrusted to him by Fahrensbach. Thus, he was taking part in the military campaign, and was sentenced on the ground of absence, which was contrary to the contents of the summons. In this judgement it was decided that Hilchen had

49 "[...] nos Davidem Hilchen, ejusque mandatorios, fide publica salvi conductus nostri, per praesens Decretum nostrum assecuramus, DECERNENTES NE QUIDQUAM VIOLENTER SUB QVOCUNQVE PRAETEXTU CONTRA EUM TENTETUR, sub poenis in violatores salui conductus nostri legibus sancitis, sed libere ad iudicium, terminis observatis, accedat et recedat, in civitatemque veniat, et cum voluerit, discedat, modo se pacate quoque in omnibus gerat, APPELLATIONE AD NOS, tanquam in causa honoris et existimationis a sententia definitiva, non obstante ullo praetextu rei iudicatae, salua: iuribus et legibus Civitatis, per hanc in negocio praesenti appellationis admissionem, non derogando praesentis Decreti nostri vigore. (D. Hilchen, Clypeus 1604, fol. Aiv verso). See about privilegies of Riga A. Karabowicz, The legal activities of King Stephen Bathory in Livonia (1576-1586), in: Einheit und Vielfalt in der Rechtsgeschichte im Ostseeraum, Frankfurt am Main 2011, pp. 109-122.

50 Johannes Myrander (Heydeman(n)) - dr. jur. (1594 Königsberg), Counsellor of the Prince of Prussia (der fürstliche preussische Rat). 
to revoke his shameful statements to Godemann within six weeks and reimburse the latter all costs. ${ }^{51}$

This letter from 10th December 1600 was written already after the first sentence against Hilchen was made. Namely, ten months after the summons to the Riga City Hall, on 15th October 1600, Hilchen was sentenced in absentia by the court in Riga (as the representative of Livonian land nobility he was just returning from the Sejm in Warsaw or already partaking in the war against Sweden in the territory of northern Livonia ${ }^{52}$ ). As a part of the punishment his picture was publicly caned ${ }^{53}$ and his possessions such as his house were confiscated or burned down. ${ }^{54}$ The second sentence against Hilchen fell on 18th (8th) May 1601 when he was sentenced to death, again in absentia, and declared an outlaw..$^{55}$

From Riga, legates were sent to the Polish King to get the sentence approved.

51 “Vt ex Decreto Regiae Maiestatis Rigae causam agerem, acta; ut vero tutus essem, assecurationem a Senatu petij. Neutrum obtinui: nec is, qui a Regia Maiestate mihi concessus fuerat, salvus conductus, restitutus est: non legitime, sed inordinate, per publicum edictum valvis Curiae affixum citatus, misi Advocatum ex Borussia evocatum Generosum Dominum Johannem Myrandrum Juris Vtriusque Doctorem et Consiliarium Dominis Prussiae, misi itidem Procuratorem. Neuter admissus, sed uterque exclusus et elusus, sub praetextu Juris, quasi in criminalibus. Procurator non admitteretur: quae, etsi usu iuris communis, saxonici et Polonici refutabantur, non tamen audiebantur. Sententia in contumatiam [sic] ipso iure nulla, in termino nullo, nulliter; praeter et extra citationis contenta, contra me Reipublicae causa absentem, et arcem Lemsaliensem, quam fidei meae Dominus Farensbachius credidit, defendentem, generalique expeditione bellica occupatum, lata est: qua decernitur, ut ego palinodiam intra sex septimanas dem subturpem Godemanno, et impensas omnes illi refundam." (1600-12-10. David Hilchen an Jan Zamoyski. ms. apograph: Warszawa Archiwum Głowne Akt Dawnych, 358 Archiv Ord. Zamoiskich Tom VII, Plik 66, fols. 20-23).

52 As the letter to Zamoyski is the only one from the second half of 1600, it is impossible to say when exactly Hilchen moved to Livonian battlefield and when he left it again. The last dated letter from Warsaw is written on 26th (16th) June 1600, the present one in Ropaži (German Rodenpois), 34 km north of Riga, the next one on 8th March 1601 in Warsaw again. His second campaign started at the latest in December 1601 by Wolmar (lett. Valmiera) and lasted until the end of January 1603.

53 H. von Ramm-Helmsing, David Hilchen..., fn 197: from Actus iudicarius.

54 A description of it is e.g. in Hilchen's letter to Andrzej Szredzińki from 8th August 1602 .

55 H. von Ramm-Helmsing, David Hilchen..., pp. 56-57. 


\section{1601-1609: Legal Proceedings at King's Court}

Hilchen immediately appealed to the Polish King and asked - as is evident from the letters - that the case should be heard in Relationsgericht. ${ }^{56}$ Hilchen, as the king's secretary and Zamoyski's protegée, hoped that his case would be solved soon - there are letters preceding every next subsequent session of Parliament (Sejm) where he expresses this hope. ${ }^{57}$ At the same time he was participating in the Polish-Swedish war in Livonia, assuming the Polish cause, between December 1601 and January 1603. From June 1603 he was based at the manor of Horyszów, near Zamość, which belonged to Zamoyski. Hilchen served there as secretary and administrator of the Academy of Zamość. Hilchen never returned to Riga, and he died in Horyszów in June 1610.58

In the beginning of exile, Hilchen was quite full of hope that his innocence will be confirmed. However, the proceedings were not only about his innocence but also concerned with many different politically or legally sensitive matters: the de non appellando privileges of City of Riga, ${ }^{59}$

56 About Polish Appeal Court System see: A. Moniuszko, King's Courts in Polish-Lithuanian Republic-Lithuania at the turn of the 17th Century, in: K. Viiding, H. Siimets-Gross, T. Hoffmann (Eds.), Letters, Law and Court in Polish Livonia: the case of David Hilchen, Münster 2021 [in publication].

57 See e.g. letter 1602-11-16 David Hilchen to Jan Zamoyski (ms. apograph: Riga LVVA 4038-2-297 p. 112), again a letter from 1602-11-25 to Jan Zamoyski. ms. apograph: Warszawa Archiwum Głowne Akt Dawnych Archiwum Zamoyskich 1/358/0/0669 fols. 19-21, where Hilchen hopes that the King would determine a date for the hearings and is not sure whether he can participate in the next battle under Narwa for that reason.

${ }^{58}$ K. Viiding, T. Hoffmann, H. Siimets-Gross, P. Sapala (Eds.), http://emlo-portal. bodleian.ox.ac.uk/collections/?catalogue=david-hilchen (access: 30.06.2020).

59 At the turn of the 16th century and during the 17th century, central state power was not yet as strong as it was in the following period of absolutism, in part because of the many privileges of the big cities such as Gdańsk or Riga. One of the most important privileges was the right to have its own jurisdiction without interference of the King. The privilegium de non appellando was given to Riga by the predecessor of Sigismund III, by Stephen Báthory 1582. Compare M. Dogiel, Codex Diplomaticus Regni Polonicae et Magni Ducatus Lithuaniae In Quo Pacta, Foedera, Tractatus Pacis, Mutuae Amicitiae, Subsidiorum, Induciarum, Commerciorum Nec non Conventiones, Pactiones, Concordata, Transactiones, Declarationes, Statuta, Ordinationes, Bullae, Decreta, Edicta, Rescripta, Sententiae Arbitrales, Infeudationes, Homagia, Pacta etiam Matrimonalia et Dotalia ... Aliaque ... Monumenta Nunc Primum Ex Archivis Publicis Eruta ac in Lucem Protracta ... exhibentur, Tomus V, Vilnius 1759, pp. 308-314, esp. 309-310. 
the relation between power and rights of the king and cities in the Early Modern Poland, the strife of power between the king and his Chancellor and Grand Hetman, Jan Zamoyski, the ongoing war between Poland and the Duke of Södermanland and later King of Sweden Charles etc. ${ }^{60}$

Hilchen was in correspondence with some of the most influential and important persons in the Polish Kingdom, e.g. with Piotr Tylicki, 1598-1605 the Vice-Chancellor of Poland, whose "outstanding virtue he highly valued". According to Hilchen's admonitory self-defense letter, Tylicki judges all cases sent to the king according to law and justice, not according to fate, rumours or false complaints. ${ }^{61}$ Hilchen was aware that the legates of the City of Riga had given the Polish king a booklet with the lawsuits against Hilchen. Tylicki postponed proceedings with the most serious accusations against Hilchen since Hilchen was on the battlefield, and sent the booklet also to Jan Zamoyski. ${ }^{62}$

Similarly, Hilchen once described his situation and the course of his trial in defensive and petitive letter to Stanisław Fogelfeder, another one of the king's secretaries: ${ }^{63}$ how his enemies forced him to shipwreck, not fairly but with cunning and deceit. Hilchen declared himself innocent, because he was invited to a duel by his enemy - Godemann, wielding a sword - and he only touched him with his cane. In Hilchen's opinion this did not represent such an injustice to be worth of destroying his life, his property and his honour. Hilchen's wish was that Fogelfeder would not believe Hilchen's opponents and would recommend him to the king as a reminder of Fahrensbach's endorsement. The king should listen to Hilchen and not use any form of violence intended by the City of Riga against him without further investigation. Hilchen - like Fogelfeder ${ }^{64}$

60 See about Polish history of this period e.g. W. Leitsch, Das Leben am Hof König Sigismunds III. von Polen, Wien 2009.

61 Tylicki studied Law in Kraków University (Album studiosorum universitatis Cracoviensis Tomus III. Ab anno 1551 ad annum 1606, Adam Chmiel (Ed.), Cracoviae 1894).

62 1602-08-08. David Hilchen to Piotr Tylicki. ms. apograph: Riga LVVA 4038-2-297 fols. 4r-5r (liber 1,6); Linköpings Stadsbibliotek/Stiftsbiblioteket, $\mathrm{Br} 43$, fols. 6r-7v (liber 1,6).

63 Stanisław Fogelfeder (1525-10.01.1603) - influential Royal Secretary and diplomat in Polen since 1567. Since his studies in Padova 1558-1562 he had contacts with Jan Zamoyski. Many diplomatic missions (in Madrid, Sweden etc), private secretary of the Queen Anna (W. Leitsch 2009, vol. 3, pp. 2063-2071).

${ }^{64}$ Fogelfeder came from a merchant family of Kraków (like Hilchen in Riga) and was ennobled even thrice: 1574 by Maximilian II., 1589 bei Philipp II. in Madrid and 1589 by Sigismund III (W. Leitsch 2009, vol. 3, pp. 2063-2071). 
was, after all, a nobleman and had to be treated according to the law applicable to nobility. In conclusion, Hilchen's request was that his case should be heard. He wished that the king would protect him and would order his enemies to refrain from violence and attacks against Hilchen. ${ }^{65}$

After leaving Riga and Livonia, Hilchen had also good ties with the Jesuits. Hilchen wrote an open-hearted, but complaining letter of defense giving his view on the causes of the legal proceedings and the persons behind them to Pater Friedrich Bartsch - the confessor of the Polish King since $1600 .{ }^{66}$ Hilchen claims that in court his guilt was by no means proven and he was merely condemned by a sworn part of the Riga City Council against all common law and Polish law. The other half of the council members remained silent or groaned under this burden. Hilchen complained about the frustration, as he had dedicated his whole life and all his work to Riga and had not committed any injustice against the city. "The initiator of the storm was Nicolaus Eck" - a former friend and colleague of Hilchen. Hilchen warned him against peculation as he would contradict his conscience. Yet, through false accusations, the king, the senators and the Jesuit priests were now alienated from Hilchen. Hilchen was accused of treason and of conspiring with Duke Charles without reason; Hilchen's efforts in regaining the fortresses were overlooked. Hilchen was described as an enemy of the fatherland and a troublemaker, although he took part in the war fearlessly and at his own expense, without it affecting the affairs of Riga. ${ }^{67}$

65 1602-09-04. David Hilchen to Stanislaw Fogelfeder. ms. apograph: Riga LVVA 4038-2-297 fol. 86r-86v (liber 2,60); Linköpings Stads- och Stiftsbiblioteket, Br 43, fols. 138r-139r (liber 2,60).

66 Friedrich Bartsch SJ (1552-1609) studied 1569-1572 in Collegium Romanum and was since 29th August 1572 member of the Jesuit Order. After his return to Poland in 1576, he was rector and professor of Greek in Braunsberg (1582-1592), $1587 \mathrm{dr}$. theol. in Vilnius and rector of the Jesuit Academy in Vilnius 1592-1595). Obviously, he had contacts with Hilchen at the latest since 1598, as he was designated to viceprovincial of Lithuania and Livonia. In May 1598 and June 1599 he visited Riga and Tartu (L. Grzebień, Encyklopedia wiedzy o jezuitach na ziemiach Polski i Litwy: 1564-1995, Kraków 1996, p. 30; V. Helk, Die Jesuiten in Dorpat 1583-1625: ein Vorposten der Gegenreformation in Nordosteuropa, Odense 1977, p. 121).

67 1602-09-05. David Hilchen to Friedrich Barthsch. ms. apograph: Riga LVVA 4038-2-297, fols. 29v-30v (liber 1,60), Linköpings Stads- och Stiftsbiblioteket, Br 43, fols. 39v-41r (liber 1,61). 
After some time, at least from 1602 onwards ${ }^{68}$ but more systematically for the publication of his defence "Clypeus Innocentiae" in 1604, Hilchen asked his correspondents - from universities, lawyers and professors across Europe, to send him testimonies and/or expert opinions (judicium) about his case and honour (de mea re et fama) ${ }^{69}$. This was an ordinary praxis in the Early Modern court proceedings, used both by parties as well as courts. ${ }^{70}$ However, usually the parties and the courts expected for the expert opinion to be a detailed analysis of the case. To one of his addresee's lawyer Thomas Dresner ${ }^{71}$ - Hilchen sent also a model that could be used. This contained only three sentences:

Since the trial itself was held under an incompetent court, as well as being itself violently and voidly opened by the Riga City Council against the Wenden notary, it must be terminated and declared invalid. He (=Hilchen) is to be restituted in his honour and his property with compensation for all damages suffered. In case of an objection from the City Council, the Royal Court of Justice is to be called upon. ${ }^{72}$

68 In this letter Hilchen thanks canonic of Chełm, Melchior Stefański (Stephanides) for sending him his opinion. 1602-10-01. ms. apograph: Riga LVVA 4038-2-297, fols. 24r-25r (liber 1,45), Linköpings Stads- och Stiftsbiblioteket, Br 43, fols. 34r-35r (liber 1,46).

69 About the question of honour and its role in the Early Modern legal proceedings see: R.-P. Fuchs, Um die Ehre. Westfülische Beleidigungsprozesse vor dem Reichskammergericht 1525-1805 (Westfälisches Institut für Regionalgeschichte. Landschaftsverband Westfalen-Lippe, Münster: Forschungen zur Regionalgeschichte 28), Paderborn 1999.

70 See about the role of universities, first of all in Germany, sending the judicii, consilii, etc.: U. Falk, Consilia. Studien zur Praxis der Rechtsgutachten in der frühen Neuzeit, Frankfurt am Main 2006.

71 Thomas Dresner (Drezner, Vondresen, Wondrezen, Tomasz, 1560-1616) - lawyer, dr. iur. 1606, professor of Law at the Academy of Zamość (1610-1616). Studied in Orléans (1601), Paris and Bourges (1602), Padova (1603-1604). Published intensively about law in Poland (Processus judiciarius Regni Poloniae, Zamość 1601, Similium juris polonici cum jure Romano, Centuria una, Paris 1602; Institutionum juris Regni Poloniae libri IV ex Statutis et Constitutionibus collecti, Zamość 1613). See also: K. Bukowska. Tomasz Drezner 1560-1616, Warszawa 1960.

72 "Cum processus iste incompetenter, violenter et nulliter a Senatu Rigensi contra Notarium Vendensem institutus est, ideo abolendus et cassandus. Ipse vero honoribus et bonis suis ante omnia cum plena damnorum satisfactione restituendus est. Si quae Senatui competit, agat coram Regia Maiestate." [terminus post quem: 1604-01-01; terminus ante quem: 1606-07-05] ms. apograph: Riga LVVA 4038-2-297, fols. 203v-204r (liber 5,90). 
In addition to the German, Dutch and Italian universities, Hilchen hoped to get an expert opinion from the University of Kraków and from its Rector Mikołaj Dobrocieski (1559-1608). Hilchen wrote that he would like to request a legal opinion on his entire trial from University of Kraków, "since the authority of the University of Kraków is greater than that of other universities". A legal opinion could be drawn up jointly by all lawyers of the University of Kraków. For this, he sent to Dobrocies$\mathrm{ki}$ an overview of the state of his trial versus the City of Riga and the decree of His Holy Majesty ${ }^{73} .74$

A more colourful version of "Clypeus" or shield, with the title "Gegenwehr der Unschuld und Warheit" (The Defence of Innocence and Truth"), was published by Hilchen a year later, in 1605. For the City of Riga, such a public defence strategy seemed more like a public offence, not a defence. ${ }^{75}$

Both court proceedings were at a standstill for a long time. On 11th April 1605 Hilchen wrote in a self-defending and narrative letter to the professor of theology in Wittenberg, Georg Mylius, ${ }^{76}$ that Godemann has been called to court several times and accused of disobedience in not appearing to the court (contumacia). Finally, Godemann appeared and proposed a compromise acknowledging the nullity of the trial. However, Hilchen

73 It could be either "Inhibitio Sacrae Regiae Maiestatis" from 19th of March 1600 by King Sigismund III or the first sentence by the Polish King from 10th June 1600.

74 "[...] tamen quantum inclytae Academiae Vestrae auctoritas major est, quam relinquarum tantum ad iustas consolationes cumulum recessurum esse video [...] Ecce enim, vir humanissime, statum causae meae contra quosdam Rigenses et Sacrae Regiae Maiestatis decretum Magnificae Reverentiae Vestrae mitto et ab ipsa eadem haec Jurisperitis omnibus Academicis meo nomine quam commode insinuari cupio ut ad dictamen rectae rationis et tenorem Juris de tota hac causa mea consilium suum mecum communicare non graventur." 1604-00-00 (terminus ante quem 1604-02-21). ms. apograph: Riga LVVA 4038-2-297, fol. 208r-208v (liber 5,107).

75 A letter of the City Council of Riga. Riga LVVA 673-1-344a, pp. 161-168.

76 Georg Mylius (1548-1527) - dr. theol., Professor of theology in Wittenberg (1585-1589, 1601-1607) and Jena (1589-1601), since 1601 Superintendent in Jena. Published 1597 in Leipzig "Christlicher Sendbrieffe an die Evangelische Christen in Liffland, Poln, Preussen, Littaw, Churland vnnd andern angrentzenden Provintzen, dass sie ihre Kinder in der Jesuiter Schulen, Collegia vnd Seminarien zuschicken, beyhöchster ihrer selbsten haben sollen", in which he called on the parents of the Protestant families to start their own schools, because the Jesuit schools lure the children into the Catholic Church. 
claimed that it really is also in his interest that the whole matter would be decided "fairly and equitably" (jure et judicio). ${ }^{77}$

Despite many years of proceedings Hilchen did not lose faith in the King's justice that he had written about in his poems already, long before the trial. ${ }^{78}$ The same hope can be seen e.g. in the summer of 1604 as the representatives of Riga attacked in the night one of the manors of his father-in-law Franz Nyenstede, looking for Hilchen and intending to arrest him. After the incident, Hilchen wrote to the Marshal of the Polish Crown a narrative and self-justifying letter and affirmed that he lays his hope in that the attackers will be punished by the King. ${ }^{79}$ Even greater trust towards the King and the Royal (Supreme) Court can be seen from the complaining letter written by Hilchen on 18th October 1607 to the Royal Polish referendarius Eustachius Wołłowicz (1572-1630). Namely, some high officials of Samogitia ${ }^{80}$ intended to bring Hilchen's proceedings from the Supreme Court to a lower court in order to finish the trial faster. Not only does Hilchen despise this unlawful change, he also does not want to entrust his life and fortune to such an untrustworthy judge. ${ }^{81}$

77 1605-04-11. David Hilchen to Georg Mylius. ms. apograph: Riga LVVA 4038-2-297, fol. 268r-268v (liber 6,2).

78 Compare one of Hilchen's poems about the King from 1595, v. 7-10: “tamen aequa lege gubernas / Singula, diuersis Sceptriger imperiis. / Iuraque das Suecis, idem sua iura Polonis / Rex, in vtrosque Pater iustus, vtrinque bonus." ("You ruler of several kingdoms govern every one of your subjects with equal right. You make laws for the Swedes, you make laws for the Poles! Oh King, a fair and good father to both"; D. Hilchen, Nomina regia trajectione quadam litterarum inter litteratos hodie vsitata, breviter expressit David Hilchen, Regiae Maiestatis per Livoniam Secretarius et Syndicus Rigensis, Cracoviae 1595, fol. Aiii-Aiii verso).

79 "Ipse cum in Illustrissima Celsitate Vestra maximam innocentiae meae spem ponam [...]". 1604-07-29 (ms. apograph: Riga LVVA 4038-2-297, fols. 73r-74r (liber 2,28); Linköpings Stadsbibliotek/Stiftsbiblioteket, Br 43, fols. 120r-121v (liber 2,28).

80 E.g. Jan Karol Chodkiewicz (1560-1621) - educated at the Vilnius Academy and the universities of Ingolstadt, Germany and Padova. The Voivode of Samogitia (1599-1616), the Field Hetman of the Lithuanian Armies (1600-1605), the Administrator of Livonia (1603-1621), and the Grand Hetman (1605-1621).

81 “Denuo interventu Illustris Domini Campiducatoris cum Illustrissimo Domino nostro Capitaneo Samogitiae in gratiam redii. Mediatore praesente omnia, quae petebam, se facturum receperat. Nunc alius est, quod ex litterarum ejus exemplo Illustritas Vestra cognoscet. Vult omnino ut se judice causa mea finiatur. Qui potest? Causa enim judicio Regio praeoccupata a Supremo Judice ad inferiorem remitti nequit nec eo me patiar adduci unquam, ut famam, vitam fortunasque illi (Panthaerinus est) credam. Ecce fiduciam." 1607-10-18 David Hilchen to Eustachius Wołłowicz (ms. apograph: Riga LVVA 
Thus, the King remained an authority for Hilchen despite the rather lengthy court proceedings.

It seems that a decisive addressee among Hilchen's correspondents was the Bishop of Chełmno (Culm) in Poland, Crown Chancellor since January 1609, Laurentius Gembic(z)ki. ${ }^{82}$ Only two letters by Hilchen to him are preserved, but already from the first of his letters can be seen that, although they had no previous correspondence, Gembicki's attitude towards Hilchen was supportive. ${ }^{83}$ In Hilchen's second letter to Gembicki, dated 18th May 1608, Hilchen complains that for eight years already he has been asking for nothing other than that someone would stand on his behalf before His Royal Majesty and the Sejm. Hilchen's innocence and suffering were to have been known throughout Poland. He points out his merits which are nothing but useless "unless justice is done to me" and that the case will be referred back to the "arbitrator chosen by both sides". Hilchen stresses that the help of Gembicki is of utmost necessity: "Nothing will move further [...] unless Your Highness offers additional help and authority. Therefore, I ask it. Please put an end to this". ${ }^{84}$

Lastly, Hilchen's correspondence also includes a defending letter written by him on behalf of Gembicki to the Riga City Council in March 1609,

4038-2-297, fol. 94r-94v (liber 2,75); Linköpings Stadsbibliotek/Stiftsbiblioteket, Br 43, fols. 148v-150r (lib. 2,75).

82 Laurentius (Wawrzyniec) Gembiczki (1559-1627) - Roman Catholic prelate, Royal Secretary until 1598, bishop of Chełmno (1600-1610), later in Włocławek (1610-1616) and Gniezno (1616-1624), protegée of Jan Zamoyski (W. Tygielski, Politics of Patronage in Renaissance Poland. Chancellor Jan Zamoyski, his supporters and the political map of Poland 1572-1605, Warszawa 1990, p. 67).

83 “Scripserat mihi Reverendus Dominus Sterbelius Scholasticus Vendensis Illustrissimam et Reverendissimam Dominationem Vestram ad meas per Generosum Dominum Heidenstein rescripturum. Non credidi nec ita factum. Quid enim Reverendissimus Episcopus Culmensis ex tanto culmine ad me scriberet? Cognovi tamen ex sermone Domini Heidenstenii veterem Reverendissimae Dominationis Vestrae erga me affectum eundem esse." 1604-04-05 David Hilchen to L. Gembicki, ms. apograph: Riga LVVA 4038-2-297, fols. 9v-10r (liber 1,15); Linköpings Stadsbibliotek/Stiftsbiblioteket, Br 43, fol. 14r-14v (liber 1,15).

${ }_{84}$ "Careant perpetuum, modo mihi vel Iustitia administretur, vel causa ad arbitros utrumque seligendos remittatur. Utrumque haerebit sine opera auxiliatricis Illustrissimae ac Reverendissimae Celsitudinis Vestrae manus. Eum igitur inploro. Cedat eam quaeso." 1608-05-18. David Hilchen to Laurentius Gembicki. ms. apograph: Riga LVVA 4038-2-297, fol. 11r-11v (liber 1,18); Linköpings Stads- och Stiftsbiblioteket, Br 43, fol. 16r-16v (liber 1,18). 
according to which it is now really the time to settle the matter of David Hilchen, as it will exhaust the city as well as affect Hilchen severely. Hilchen stressed, on behalf of Gembicki, that Hilchen was not being attacked by the city but only by some of his envious enemies and so it is the time to end it all. According to the letter, the only way to resolve this conflict would be to restore mutual harmony. On behalf of Gembicki it is stressed that he is willing to help both sides and find a solution that restores the rights and reputation of both sides. He would like to have the answer of the Riga Council to this proposal as soon as possible. ${ }^{85}$ It seems that this letter actually had an effect because within only two months the proceedings were terminated by decree of the King, and Hilchen was restituted in honour and property.

Both proceedings regarding Hilchen were terminated with a decision by the King and his court in May 1609. Hilchen was finally exculpated and all his property and positions were restituted:

"It is in the utmost interest of the State that court disputes arising between parties should not be eternal, rather, they should be resolved and terminated as quickly as possible. Additionally, to make a decision in the interest of public peace and tranquillity and for the peace of mind and honour of the disputing parties of the present proceedings, which have come to Us through appeal and have been encumbering both parties all these long years [...] Files, facts, edicts, testimonies, instruments, public and private investigations, relations, sureties, real and verbal executions, disputes, the decrees of the City Council of Riga, documents and Clypeus - all We repeal and declare invalid and the present applicant, David Hilchen, is exculpated of all criminal accusations as an honest and innocent man $[. .$.$] whose good reputation and respectability may not be dam-$ aged by anyone at no point in time. ${ }^{86 \prime}$

85 1609-03-12. Hilchen on behalf of Gembicki to City Council of Riga. ms. apograph: Riga LVVA 4038-2-297, fols. 155v-156r (liber 3,76); Linköpings Stads- och Stiftsbiblioteket, Br 43, fol. 299r-299v (liber 3,79).

86 "[...] quod maxime intersit Reipublicae, ne lites et controversiae inter partes exortae sint immortales, sed quantocius sopiantur et determinantur, ideo ut et paci et tranquillitati publicae, et partium recensitarum quieti et honori consultum sit, causam praesentem per appellationem ad nos devolutam, et cum gravi utriusque partis dispendio per tot annos agitatam [...] acta, facta, edicta, testimonia, instrumenta,inquisitiones publicas et privatas, relationes, cautiones, executiones tam reales quam verbales, controversias ante et post interpositam actoris moderni appellationem, quomodocunque et ubicunque agitatas, tum etiam 


\section{Conclusion}

This case study from the Early Modern Polish province of Livonia demonstrated the importance of including the private letters to the research of the court proceedings, especially of combining and comparing them with the official court documents (summons, decrees) as well as with the privileges and other administrative regulations. First, a close reading of the letters revealed that in Hilchen's case, two proceedings took place at the same time. Second, despite the privilegium de non appellando for the Polish Riga, Hilchen appealed to the Polish King twice during the proceedings. On the first occasion, his argument was that on the basis of the King's decree, the court should not have been summoned at all, as he had the right to be absent because of partaking the military campaign. The second time, the argument concerned unlawful proceedings in general, and also being absent in state interests. During the second time, the legal basis for Hilchen's appeal was also the King's permission to do it for the justice to be done. The justice or aequitas has been an important tool for extending the central power in general and also in Poland. ${ }^{87}$

Third, it became clear from the letters that some high officials intended to bring Hilchen's proceedings from the King's Court back to a lower court in order to finish the trial faster. Thus, it presents a good example of how, despite many legal obstacles over an elongated period, a case could move from city jurisdiction to state jurisdiction, even at a time when royal power was not at its strongest.

Even as the humanist letters had often mixed content and functions (epistulae mixtae), Hilchen preferred to use certain types of letters in

decreta sub titulo Senatus Rigensis, nec non libellos, atque in eis Clypeum et quaevis alia et quacunque lingua ex utraque parte per hoc Regnum et alia loca passim sparsa, ac quocunque nomine edita siue scripta siue impressa tollimus, abrogamus, cassamus, et actorem modernum Davidem Hilchen ab omnibus illi obiectis criminibus vti virum bonum et innocentem absolvimus, et perpetuo liberum pronunciamus, decernentes, quod eiusmodi processus subsequutique effectus eiusdem Davidis Hilchen, eiusque haeredum ac successorum bonae Famae et existimationi nullo unquam tempore nocere debeant." Decretum Sacrae Regiae Maiestatis in causa Hilchenij Anno 1609. Apograph: Hilcheniana oder die verschiedenen zu der Stadtes Syndici Godemanni und [...] Rathes [...] wieder dem Städte Syndicum David Hilchen [...]. Riga LVVA 673-1-344 e, second copy pp. 114-116.

87 See also M. Jonca, "Multa turbat temeritas fortunae“: zwei Briefe von Stanistaw Żótkiewski in Sachen David Hilchen, in: K. Viiding, H. Siimets-Gross, T. Hoffmann (Eds.), Letters, Law and Court in Polish Livonia: the case of David Hilchen, Münster 2021 (in publication). 
combination. During the first half of his proceedings he wrote mainly petitive and communicative letters, but after 1605 in reflecting his own case the defensive, self-justifying and complaining letters prevailed. This may have been partly due to the fact that in 1605 his patron Jan Zamoyski died and Hilchen had to take over the advocating function of his patron. On the other hand, the trial of Hilchen was clearly not an ordinary court case but with many specific nuances like today's political trials. This aspect, concerning the trial in Riga, was mentioned by Jan Zamoyski and Petrus Tylicki in their support letters, asking for a fair and unpolitical trial. This was clearly not achieved. Political aspects were present also during the appeal. On the one hand, the difficult relations between Hilchen's patron Zamoyski and the King were reflected in the proceedings. On the other hand, the solution needed the political will to be decided and here, the relation of Hilchen to high officials of Polish-Lithuanian Commonwealth played a role. The political nature of the process is also the reason why the letters can contribute much for understanding the course and specifics of the proceedings.

Even as the trial of Riga seems to have been unfair as the prosecutor and the court had the same members and the procedural rules were not always followed, the King had to intervene to restore the aequitas in his kingdom. Thus, the decision by Sigismund III in the trials of Hilchen relies more on the general interest of the State to have peace and no disputes other than legal arguments. Nevertheless, the political situation and the questions of power in the Commonwealth were not without importance either. Thus, the dispute and whole situation between city of Riga and Hilchen had to be pacified and the main adversaries of Hilchen, Nicolaus Eck(e) and Jakob Godemann, had to leave Riga.

Hilchen believed in the influence of the humanist letters. He included the most representative defending letters of his patrons and supporters in his apologetic treatises, he used his network of correspondents for spreading the message of his innocence and asking the legal opinion about it in the Polish-Lithuanian Commonwealth and in the European respublica litteraria - eventually it had the hoped effect. In the end, the private letter about Hilchen and even by Hilchen (in the name of Gembicki) had a crucial role influencing King's final decision. Thus, the confidence Hilchen had in the Early Modern Polish legal system and its fairness was, in the end, justified with the help of letters. 


\section{Bibliography}

\section{Literature}

Album studiosorum universitatis Cracoviensis Tomus III. Ab anno 1551 ad annum 1606, Adam Chmiel (Ed.), Cracoviae 1894.

Bukowska K., Tomasz Drezner 1560-1616, Warszawa 1960.

Catharini Santonellae Horti Musarum in Monte Helicone custodis [=David Hilchen] contra Cerberum [=Georg Herbers] in Elysijs vallibus excubitorem Heliconi oblatrantem Satyra, S.1, s.a. [Riga 1599].

Decretum regium inter generosum Davidem Hilchen Sacr. Reg. Mtis. et Secretarium et Notarium Terrestrem Vendensem Actorem: et Spectabilem Senatum Rigensem, una cum parte adhaerente egregio Iacobo Godemano Citatum Varsaviae die X. Iunij Anno MDC latum. Cui adnexum est Rescriptum Regium, Vilnae 1600.

Dogiel M., Codex Diplomaticus Regni Polonicae et Magni Ducatus Lithuaniae In Quo Pacta, Foedera, Tractatus Pacis, Mutuae Amicitiae, Subsidiorum, Induciarum, Commerciorum Nec non Conventiones, Pactiones, Concordata, Transactiones, Declarationes, Statuta, Ordinationes, Bullae, Decreta, Edicta, Rescripta, Sententiae Arbitrales, Infeudationes, Homagia, Pacta etiam Matrimonalia et Dotalia ... Aliaque ... Monumenta Nunc Primum Ex Archivis Publicis Eruta ac in Lucem Protracta ... exhibentur, Tomus V, Vilnius 1759.

Erasmus Rotterodamus, De conscribendis epistolis opus, Lugduni 1542.

Falk U., Consilia. Studien zur Praxis der Rechtsgutachten in der frühen Neuzeit, Frankfurt am Main 2006.

Friedrich A.C.A., Darstellung Alt- und Neupolens, Berlin 1839.

Fuchs R.-P., Um die Ehre. Westfälische Beleidigungsprozesse vor dem Reichskammergericht 1525-1805 (Westfälisches Institut für Regionalgeschichte. Landschaftsverband Westfalen-Lippe, Münster: Forschungen zur Regionalgeschichte 28), Paderborn 1999.

Görgen A., Rechtssprache in der Frühen Neuzeit. Eine vergleichende Untersuchung der Fremdwortwendung in Gesetzen des 16. und 17. Jahrhunderts, Frankfurt/M et al. 2002.

Gottzmann C. L., Hörner P., Lexikon der deutschsprachigen Literatur des Baltikums und St. Petersburgs, Berlin 2007.

Grzebień L., Encyklopedia wiedzy o jezuitach na ziemiach Polski i Litwy: 1564-1995, Kraków 1996.

Helk V., Die Jesuiten in Dorpat 1583-1625: ein Vorposten der Gegenreformation in Nordosteuropa, Odense 1977.

Henderson J.R, Humanist Letter Writing: Private Conversation or Public Forum?, in: T. Van Houdt, J. Papy, G. Tournoy, C. Matheuussen (Eds.), Self-presentation 
and Social Identification. The Rhetoric and Pragmatics of Letter Writing in Early Modern Times, Leuven 2002.

Hilchen D., Disputatio de successione ex testamento. Qvam Divini numinis auspicio, praeside clarissimo viro D. Andrea Laubmario, V.I.D. et in celeberrima Tubingensi Academia ordinario professore, praeceptore suo singulariter observando, die 29. Maji hora 6. In auditorio Jureconsultorum, ingenij exercendi gratia, defendere conabitur David Heliconius, Livonus, Tubingae 1584.

Hilchen D., De legatis et fideicommissis disputatio in antiqua Heidelbergensi academia sub excellentissimi viri Domini Matthiae Entzellini V.J.D. et professoris ordinarii: Praeceptoris sui omni officio observandi praesidio: ingenii retexendi gratia publice proposita a Davide Heliconio Livono die 20. Februarii horis ante et pomeridiani discutienda, Heydelbergae 1585.

Hilchen D., Nomina regia trajectione quadam litterarum inter litteratos hodie vsitata, breviter expressit David Hilchen, Regiae Maiestatis per Livoniam Secretarius et Syndicus Rigensis, Cracoviae 1595.

Hilchen D., Clypevs innocentiae et veritatis Davidis Hilchen. Serenissimi Sigismondi iii. Poloniae et Sveciae Regis Secretarij, et Notarij Terrestris Vendensis contra Iacobi Godemanni Lvnebvrgensium et Rigensium quorundam, Senatus nomine ad proprium odium abutentium, cum iniquissima crudelissimaque quaedam decreta, tum alia calumniarum tela, editus, Zamość 1604.

Hilchen D., Gegenwehr der Unschuld und Warheit. Wieder Jacob Godemans Luneburgensis, und etzlicher des Rathes zu Riga Rethleinfürer gesprengte calumnien, schmeund schandlibellen. Durch den Edlen und Ehrnvesten David Hilchen, Kon. May. zu Polen und Schweden Secretarien und Wendischen Landschreiber offentlich auffgestellet, Kraków 1605.

Hüppe S., Verfassung der Republik Polen, Berlin 1867.

Ianociana sive clarorum atque illustrium Poloniae auctorum, vol. 2, Varsaviae et Lipsiae 1779.

Ius municipale Magdeburgense. Ex optimis itidem Exemplaribus latinis ac teutonicis, pari studio ac fide Polonice reditum per Paulum Sczerbicz, Leopoli 1581.

Justi Lipsii Politicorum sive civilis doctrinae libri sex, e latino sermone in Polonicum convertit Paulus Sczerbicz, Cracoviae 1595.

Jonca M., "Multa turbat temeritas fortunae": zwei Briefe von Stanisław Żótkiewski in Sachen David Hilchen, in: K. Viiding, H. Siimets-Gross, T. Hoffmann (Eds.), Letters, Law and Court in Polish Livonia: the case of David Hilchen, Münster 2021 (in publication).

Karabowicz A., The legal activities of King Stephen Bathory in Livonia (1576-1586), in: Einheit und Vielfalt in der Rechtsgeschichte im Ostseeraum, Frankfurt am Main 2011.

Königlicher Mayestat DECRET vnnd MANDAT, die zwischen dem Edlen vnnd Ehrnuesten Dauid Hilchen Königlichen Secretarien inn Liffland ond Wendischen Landt 
Notarien Klegern/ vnnd einem Erbaren Ratth von Riga Beklagte zunebenst dem Namhafften Jacob Godeman jungsthin zu Warschaw den 10 Junij 1600 ergangen, Wilde [sic] 1600.

Krüger P., Mommsen T. (Eds.), Corpus iuris civilis. Editio streotypa, vol. 1: Institutiones. Digesta, Berolini 1922.

Leitsch W., Das Leben am Hof König Sigismunds III. von Polen, Wien 2009.

Leliwa S., Dawid Hilchen. Szkic biograficzny na tle dziejów inflancko-polskich osnuty, “Biblioteka Warszawska" 1880, 157.1.

Lepri V., Knowledge Transfer and the Early Modern University: Statecraft and Philosophy at the Akademia Zamojska (1595-1627), Leiden 2019.

Lück H., Urban Law: the Law of Saxony and Magdeburg, in: H. Pihlajamäki, M.D. Dubber, M. Godfrey (Eds.), The Oxford Handbook of European Legal History, Oxford 2018.

Mack P., A History of Renaissance Rhetoric 1380-1620, Oxford 2011.

Mohnhaupt H., Grundlinien in der Geschichte der Gesetzgebung auf dem europäischen Kontinent vom 16. bis 18. Jahrhundert. Ein experimenteller Überblick, Zeitschrift für Neuere Rechtsgeschichte 2006, No 1/2.

Moniuszko A., King's courts in the Polish-Lithuanian Republic at the turn of the 17th century, in: K. Viiding, H. Siimets-Gross, T. Hoffmann (Eds.), Letters, Law and Court in Polish Livonia: the case of David Hilchen, Münster 2021 (in publication).

Orationes tres: E quibus duae honoratissima dignitate, tum sapientia et virtute ornatissimorum D.D. Scholarcharum, Nicolai Ekii, Proconsulis: et Davidis Hilchen Syndici. Tertia Ioannis Rivii, cum solenni et publico ritu produceretur, ad demandatam sibi ab Amplissimo Senatu Inspectionem Scholasticam Ineundam. Habitae in restitutione seu instauratione Scholae Rigensis XV. CLS. VILS. Adiuncta sunt iisdem: primum, publicae doctrinae series, tabellis expressa: inque curias $V$. distributa. Deinde, docendi in singulis curiis, praescripta ratio et demonstratum iter, quod utiliter Praeceptores hujus Ludi sequerentur: cum in tradendis artibus: tum in tractando et interpretando omni genere, utriusque linguae, Autorum, Rigae 1594.

von Ramm-Helmsing H., David Hilchen 1561-1610. Syndikus der Stadt Riga, Posen 1936.

Siimets-Gross H., A Letter from Detention: The Edition of Letters of Livonian Humanistic Lawyer David Hilchen as an Interdisciplinary Challenge, in: V. Amorosi; V.M. Minale (Eds.), History of Law and other Humanities: Views of the Legal World Across the Time, Madrid 2019.

Speculum Saxonum, hoc est ius provinciale Saxoniae, ex optimis exemplaribus Latinis Teutonisque cum industria et fide maxima, in linguam Polonicam translatum per Paulum Scerbicz, Leopoli 1581.

Szczerbicz P., Promptuarium Statutorum Omnium et Constitutionum Regni Poloniae per Paulum Scerbic Secretarium Sacrae Regiae Maiestatis conscriptum cum indice 
rerum et verborum copiosissimo singulari eiusdem Pauli Sczerbic studio et diligentia confecto, Brunsbergae 1605.

Tering A., Eesti-, liivi- ja kuramaalased Euroopa ülikoolides 1561-1798 [Estonians, Livonians and Curonians in the European Universities 1561-1798], Tartu 2008.

Tering A., Lexikon der Studenten aus Estland, Livland und Kurland an europäischen Universitäten 1561-1800. Unter Mitarbeit von Jürgen Beyer (Quellen und Studien zur baltischen Geschichte 28), Köln-Weimar-Wien 2018.

Trelińska B., Album armorum nobilium Regni Poloniae XV-XVIII saec: herby nobilitacji i indygenatów XV-XVIII w., Warszawa 2001.

Tygielski W., Politics of Patronage in Renaissance Poland. Chancellor Jan Zamoyski, his supporters and the political map of Poland 1572-1605, Warszawa 1990.

Van Dam H.-J., Poems on the Threshold: Neo-Latin carmina liminaria, in: A. Steiner-Weber, Enenkel K.A.E. (Eds.), Acta Conventus Neo-Latini Monasteriensis. Proceedings of the Fifteenth International Congress for Neo-Latin Studies (Münster 2012), Leiden-Boston 2015.

Viiding K., Gefährliche Bücher, gefährliche Gattungen, gefährliche Vorlagen: Die Geburt der Satire in Livland, in: O. Merisalo (Ed.), Book in context. Renæssanceforum 2019, No 15, http:/ / www.renaessanceforum.dk/rf_15_2019.htm.

Viiding K., Klöker M. (Eds.), Sub velis poeticis. Lateinische Gedichte. Mit Übersetzungen und einer Einleitung, Münster 2021.

Watson A. (Ed.), The Digest of Justinian, vol. 1, Philadelphia 2009.

Ziemlewska A., "Rozruchy kalendarzowe” w Rydze (1584-1589), Zapiski Historyczne 2006.

\section{Internet databases}

Viiding K., Hoffmann T., Siimets-Gross H., Sapala P. (Eds.), The Correspondence of David Hilchen, in: Early Modern Letters Online, Cultures of Knowledge, http:/ / emlo-portal.bodleian.ox.ac.uk/collections/?catalogue=david-hilchen (access: 30.06.2020).

\section{Sum mary}

This article offers an insight to the Early Modern Polish history of law from an unusual perspective: namely, which was the contemporary view to the Polish legal and especially court system. For that, an almost unexplored Early Modern source, the unpublished Latin correspondence by the central humanist of Polish Livonia David Hilchen (1561-1610), is used. In this paper, the principal issue touched by him, his own legal proceedings in the Polish-Lithuanian Commonwealth before the Livonian (Riga's) and Polish courts against Riga City Council are dealt with. It presents a good example of how, despite many legal obstacles 
over an elongated period, a case could move from under city jurisdiction to state jurisdiction, even at a time when royal power was not at its strongest.

Key words: Polish legal system, Early Modern epistolography, legal themes in letters, liminary poetry, Livonian humanism, legal humanism

\section{DAWID HILCHEN, PRAWNIK I HUMANISTA PRZED SĄDAMI POLSKIMI I POLSKO-INFLANCKIMI W LATACH 1600-1609. ZARYS PROCEDURY W LISTACH}

\section{Streszczenie}

Artykuł umożliwia wgląd w polską historię prawa czasów wczesnonowożytnych z niezwykłej perspektywy, a mianowicie z punktu widzenia współczesnych uczestników polskiego systemu prawnego, w szczególności systemu sądowego. $\mathrm{Z}$ tego względu niniejsza praca prezentuje niezgłębiane dotąd źródła epoki wczesnonowożytnej, niepublikowane listy w języku łacińskim głównego humanisty Polskich Inflantów, Dawida Hilchena (1561-1610). Artykuł koncentruje się na zasadniczej kwestii wskazanej przez Hilchena, jego własnym udziale w postępowaniach przed inflanckimi (ryskimi) i polskimi sądami w powództwie przeciw Ryskiej Radzie Miasta na terytorium Rzeczypospolitej Obojga Narodów. Przypadek ten stanowi dobry przykład tego, jak łatwo sprawa, pomimo wielu obostrzeń prawnych na przestrzeni dłuższego okresu i mimo nie najsilniejszej w tym czasie władzy królewskiej, była w stanie zmienić swoją właściwość z jurysdykcji miasta na właściwość państwową.

Słowa kluczowe: polski system prawny, epistolografia czasów nowożytnych, wątki prawne $\mathrm{w}$ listach, pochwalny/gratulacyjny wiersz wprowadzający, inflancki humanizm, humanizm prawniczy

\section{ДАВИД ХИЛЬХЕН, ЮРИСТ И ГУМАНИСТ В ПОЛЬСКИХ И ПОЛЬСКО-ЛИВОНСКИХ СУДАХ В 1600-1609 ГОДАХ. КРАТКОЕ ИЗЛОЖЕНИЕ ПРОЦЕДУРЫ В ПИСЬМАХ}

\section{Резюме}

В статье дается взгляд на польское право раннего Нового времени с необычной точки зрения, а именно с точки зрения современных участников польской правовой системы, в частности судебной системы. По этой причине в настоящей работе представлены неизвестные до сих пор источники эпохи 
раннего Нового времени, неопубликованные письма на латыни главного гуманиста польских инфантов Давида Хильхена (1561-1610). Статья посвящена основному вопросу, обозначенному Хильхеном, - его собственному участию в разбирательствах в Ливонском (Рижском) и польском судах по иску против Рижской думы на территории Речи Посполитой Обоих Народов. Этот случай является хорошим примером того, как легко это дело, несмотря на многие правовые ограничения в течение длительного периода и несмотря на не самую сильную королевскую власть в то время, смогло изменить свою юрисдикцию с юрисдикции города на юрисдикцию государства.

Ключевые слова: польская правовая система, переписки Нового времени, юридические темы в письмах, похвальная/поздравительная вступительная строфа, ливонский гуманизм, правовой гуманизм 
